\title{
Study on Risk Communication Model of Stakeholders in the Flood Control of River Basin Based on the IOI Technology
}

\author{
Yi Liang ${ }^{1,2}$ Chongfu Huang ${ }^{1,2, *}$ \\ 1State Key Laboratory of Earth Surface Processes and Resource Ecology (Beijing Normal \\ University), Beijing 100875, China \\ 2Academy of Disaster Reduction and Emergency Management, Ministry of Civil Affairs \& Ministry of \\ Education, the Peoples' Republic of China, Beijing 100875, China
}

\section{基于智联网技术的流域水库群防洪利益相关者风险 沟通模式研究}

\author{
梁屹 $^{1,2}$, 黄崇福 ${ }^{1,2, *}$ \\ 1 地表过程与资源生态国家重点实验室(北京师范大学), 北京 100875 , 中国 \\ 2 民政部/教育部减灾与应急管理研究院, 北京 100875, 中国
}

\begin{abstract}
Risk communication is one of the important risk management tools for stakeholders to achieve consensus. In the flood disaster risk governance, effective risk communication between the stakeholders of the flood control on basin reservoirs is an important way when flood could not avoid. Aiming at the shortage of the traditional one-way model of risk communication, discusses the watershed reservoir group flood control benefit correlation model of risk communication based on IOI technology; defines basin reservoir group flood control stakeholders and sort out the role of each bear; analysis of the interests of the various stakeholders concerns; pointed out the problems
\end{abstract}

基金项目: 国家重大科学研究计划“全球变化与环 境风险演变过程与综合评估模型”（编号: 2012CB955402)

作者简介: 梁屹, 博士研究生, 主要从事自然灾害 风险分析与模拟、 $3 \mathrm{~S}$ 技术二次开发、网络数据挖掘 和智联网等研究, E-mail: liangyi8602@126.com *通讯作者: 黄崇福, 教授, 主要从事自然灾害风 险分析和智联网等方面研究, E-mail: hchongfu@bnu.edu.cn and challenges of the stakeholders of the flood risk communication mode, and looks forward to the stakeholders of the flood risk communication IOI platform application prospect. This study could rich flood disaster risk management basic theory, provides a starting point for water conservancy departments of the government in reservoir basin group management, enhance the operability of the river basin flood control management, and so on.

Keywords: Internet of intelligences, reservoir group, stakeholders, risk communication

摘要

风险沟通是利益相关者取得共识的重要风险 治理工具之一。在洪水灾害风险治理中, 在防 洪利益相关者之间就流域水库群的防洪临灾 联合调度开展有效的风险沟通是在洪水无法 避免的情况下采取联合措施来促使流域洪水 灾害的损失降到最低的重要途径。针对传统单 向风险沟通模式的不足, 本文探讨了智联网技 术的流域水库群防洪利益相关者风险沟通模 式; 界定了流域水库群防洪利益相关者的类型 
并梳理了其各自所承担的角色; 分析了各利益 相关者的利益关切; 指出防洪利益相关者风险 沟通模式的问题与挑战, 展望了防洪利益相关 者风险沟通智联网平台的应用前景。这有利于 丰富洪涝灾害风险管理基本理论体系, 为政府 水利部门进行流域水库群的管理提供抓手, 增 强流域防洪管理的可操作性。对于解决防洪与 兴利矛盾以及常规调度造成的洪水资源浪费 问题具有一定的理论和实践意义。

关键词: 智联网, 水库群, 利益相关者, 风险 沟通

\section{1.引言}

水资源在人类生产生活中占有极其重要 的作用和地位。在水资源及能源日益匮乏的今 天, 水库在保障人类生产和生活用水、蓄能发 电和拦洪削峰等方面的作用愈发明显。如何对 水库进行合理的调度是做关流域及其影响区 域居民生产生活除害和兴利的重要课题。在全 球变化加剧, 极端天气频繁, 新媒体技术推动, 公众风险意识提高等背景下, 地处洪水风险区 域的居民以及水库企业、政府部门、保险企业 等不同防洪利益相关者在汛期对于水库调蓄 情况的关注度逐步提高。居民和水库企业关注 对其有影响的上游水库调度问题, 而政府和保 险企业等利益相关者更关注的是流域内部所 有水库之间的联合调度问题。因此, 在上述不 同防洪利益相关者之间就流域水库群的防洪 临灾联合调度开展有效的风险沟通是在洪水 无法避免的情况下采取联合措施来促使流域 洪水灾害的损失降到最低的重要途径。

风险沟通 (Risk communication) 较为常 用的定义由美国国家研究委员会提出, 即认为 风险沟通是个体、群体及机构组织间交换风险 信息和看法的相互作用的过程 ${ }^{[1]}$ 。它涉及多方 面的风险性质及其相关信息, 因此, 在风险沟 通过程中，不仅直接传递与风险有关的信息， 也包括表达对风险事件的关注、意见和对相应 行动的反应, 以及发布国家或机构在风险管理 方面的政策法规和措施等。我国 “风险沟通” 研究始于 2003 年谢晓非等人对 SARS 中公众 认知的研究 ${ }^{[2]}$ 。在灾害学领域, 祝雪花等人通 过调查受灾民众及未受灾民众对台风等重大 灾害性事件的风险认知及预警情况, 并且比较
两者的差异, 为政府对重大灾害性事件建立预 警管理模式提供依据 ${ }^{[3]}$ 。钟景鼎 ${ }^{[4]}$ 和李明 ${ }^{[5]}$ 等 人分别对区域水灾和旱灾的风险感知/认知进 行调查并提出了相应的灾害风险沟通对策。这 些研究尝试为提高我国灾害风险治理水平提 供了有益的借鉴。但是在在流域洪水风险沟通 领域, 相关研究还很缺乏, 因此, 有必要在水 库企业、政府部门、保险企业和公众居民充分 对区域洪涝灾害风险有效沟通的基础上, 综合 考虑水库企业、政府部门、保险企业和公众居 民等各利益相关方的核心关切, 进行风险辨识 和估计, 并做出较为理想的临灾调度决策, 一 方面可以在保证水库安全的前提下, 使水库尽 可能地多蓄水, 达到充分利用洪水资源, 保障 供水的目的, 另一方面也将丰富洪涝灾害风险 管理基本理论体系, 为政府水利部门进行流域 水库群的管理提供抓手, 增强流域防洪管理的 可操作性。这对于解决防洪与兴利矛盾以及常 规调度造成的洪水资源浪费问题具有重要的 理论和实践意义。

\section{2. 流域水库群防洪利益相关者分析}

\section{1. 流域水库群防洪利益相关者界定}

流域水库群洪水风险沟通的核心在于利 益相关者的界定。利益相关者的参与程度很大 程度影响了流域洪水风险治理的成效。现今越 来越多的国家和地区将公众纳入到政策决策 的制定中来。利益相关者的参与会增强流域洪 水风险治理的支持度, 提高流域洪水风险治理 政策措施的执行效率。基于流域水库群洪水风 险, 本文将流域水库群防洪利益相关者归纳为 政府部门、流域管委会、专家学者、公众和普 通企业、保险企业及水库等六大类型 (图 1)。 当然这些类型内部可以继续划分为小的类型, 例如可以将政府部门进一步细化为水利部门、 气象部门、民政部门等; 可以将专家学者按照 所从事的学科领域进一步划分为水利专家、气 象专家、灾害专家、心理专家和社会专家等。

\section{2. 利益相关者在流域水库群洪水风险沟通 中的角色}

面对流域水库群洪水风险, 不同的利益 相关者所扮演的角色各不相同，其中政府部 门、流域管委会和保险企业主要承担的是洪 水风险管理的角色, 专家学者主要承担的是 
Risk Analysis and Crisis Response in Big Data Era (RAC-16)

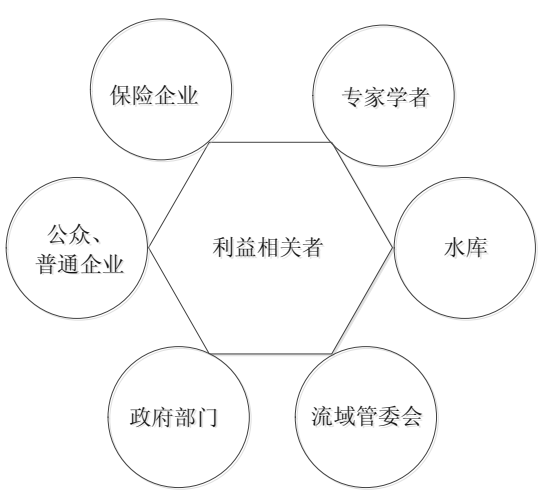

图 1. 流域水库群防洪利益相关者

洪水分析的角色, 而公众和普通企业则主要 扮演的是风险感知的角色。不同的利益相关 者之间通过信息交流和沟通联系成一个有 机整体，相互之间互相支持 (图 2)。例如专 家学者为政府部门、流域管委会、水库和保 险企业等提供辅助决策支持, 为公众答疑释 惑; 政府部门及流域管委会为专家学者、保
例如, 处于流域上游低风险区域的公众和处于 流域下游高风险区域的公众对于洪水风险的 感知和关注是有差别的。同样, 与普通的企业 大多只关注对其自身有影响的上游的泄洪不 同, 保险企业更关注的是在洪水灾害不可避免 的情况下, 流域各个水库之间能在灾害来临之 前通过放水预留尽可能大的库容以应对即将 来临的洪水灾害。而对于水库企业来说, 在天 气预报的不确定性依然非常大的情况下, 提前 放水需要承担巨大的风险和压力。表 1 列举了 部分流域水库群防洪利益相关者的利益关切 及其在流域水库群洪水风险沟通中所能提供 或需要提交和收集的数据和信息。

\section{3. 流域水库群防洪利益相关者的风险沟通模} 式

3.1. 流域水库群防洪利益相关者的风险沟通 模式

风险瞬息万变, 因此需要一个媒介来传递 和交流防洪利益相关者之间的信息。传统的风 险沟通媒介主要是电视、广播、报纸、电话、

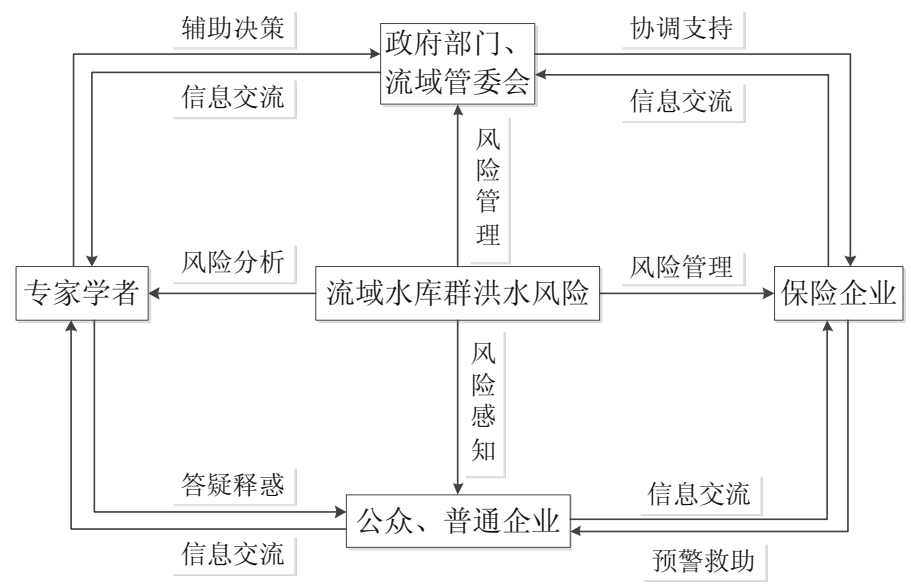

图 2. 利益相关者在流域水库群洪水风险沟通中的角色

险企业及公众等提供相应的洪水风险信息; 保险企业向政府部门提供其所掌握的风险 信息, 为其客户提供风险预警信息等; 公众 向政府部门及专家学者提供其所感知的风 险信息等。

\section{3. 流域水库群防洪利益相关者的利益关切}

不同的利益相关者由于其所为环境的不 同, 其对同一风险事件的感知也是不一样的。
短信等传统媒体。随着互联网等新媒体的出现 及公众公共事务参与意识的提高, 风险沟通的 模式也由强调权威控制、专家决策的单向沟通 向关注公众认知、多元沟通的双向沟通转变。 因此洪水风险沟通也必须改变传统的风险告 知、说服和教育导向, 应该将利益相关者之间 的意见和建议纳入风险决策的参考之中。这样 多个利益相关者可以共同商讨可接受的风险 
Risk Analysis and Crisis Response in Big Data Era (RAC-16)

表 1. 流域水库群防洪利益相关者的利益关切及沟通信息

\begin{tabular}{|c|c|c|c|}
\hline \multicolumn{2}{|c|}{ 利益相关者 } & \multirow{2}{*}{$\begin{array}{c}\text { 交流信息 } \\
\text { 历史/实时水雨情信息数据等 }\end{array}$} & \multirow{2}{*}{$\begin{array}{l}\text { 利益关切 } \\
\text { 水利设施安全等 }\end{array}$} \\
\hline 政 府 & 水利部门 & & \\
\hline \multirow[t]{4}{*}{ 部门 } & 气象部门 & 历史/实时天气数据、天气预报数据等 & 天气数据的准确性与可用性等 \\
\hline & 民政部门 & 救援物质储备、应急避难设施等 & 影响人口及土地等 \\
\hline & 市政部门 & 用水供需及其预测数据等 & 城市管网泄排情况、城市供水安全等 \\
\hline & 交通部门 & 潜在风险路段等 & 道路受淹损毁情况、道路通畅情况等 \\
\hline 流 域 & 流域协同部门 & 流域城市/乡镇准备情况等 & 流域协作调度准备与应对情况等 \\
\hline 管 委 & 流域管理部门 & 流域历史洪水数据等 & 防灾减灾措施科学性与合理性、流域水库 \\
\hline 会 & & & 群联合调度等 ～～～～～～～～～等 \\
\hline 专 家 & 水利专家 & 水库蓄水安全评估、流域水文模拟、水库群 & 水文数据的准确性与时效性、水文分析的 \\
\hline \multirow[t]{6}{*}{ 学者 } & & 联合调度等 & 不确定性、水库群联合调度的科学性等 \\
\hline & 气象专家 & 临灾天气预报等 & 临灾天气预报的准确性等 \\
\hline & 灾害专家 & 洪水淹没模拟、损失预估等 & 风险分析数据的获得性、风险评价及损失 \\
\hline & & & 预估结果的准确性等 \\
\hline & 心理专家 & 公众风险认知调查与评估等 & 公众风险感知、公众心理变化情况等 \\
\hline & 社会专家 & 沟通网络效率评价等 & 决策的社会影响等 \\
\hline \multirow[t]{6}{*}{ 公众 } & 防灾减灾信息 & 辖区老幼病残、高危人口等 & 收据收集的准确性与完整性、信息传达的 \\
\hline & 员 & & 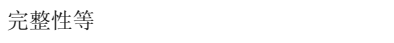 \\
\hline & 普通企事业单 & 单位职工数量、易损品及危险品情况等 & 单位影响程度及损失大小、上游水库有无 \\
\hline & 位 & & 风险等 \\
\hline & 普通公众 & 历史受淹和家财影响状况、撤离所需时间等 & 家庭影响程度及损失大小、上游水库有无 \\
\hline & & & 风险等 \\
\hline \multirow{2}{*}{\multicolumn{2}{|c|}{ 保险企业 }} & 投保企事业及个人及其区域分布情况数据信 & 投保人及企业受灾风险、水库是否及时调 \\
\hline & & 息等 & 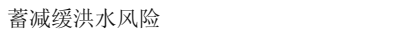 \\
\hline \multirow{2}{*}{\multicolumn{2}{|c|}{ 水库 }} & 水库等级、库容曲线、影响区域、实时/控制 & 在保障水库安全的前提下尽可能多的蓄 \\
\hline & & 库容/水位、安全隐患等 & 水等 \\
\hline
\end{tabular}

等级, 以使各方的自身利益适应于社区、集体 的利益。

在本文设计的流域水库群防洪利益相关 者的风险沟通模式中, 首先确定我们的风险问 题是解决流域水库群的调度决策问题; 然后 界定该问题所涉及到的利益相关者, 及政府 部门、流域管委会、专家学者、公众和普通企 业、保险企业及水库等; 接着借助于风险沟通 平台所展示的流域信息, 各利益相关者提供自 身所涉及的数据信息及意见关切; 接下来专家 学者可以利用风险沟通平台等收集到的数据 信息及意见关切构建流域洪水风险情景; 进而 开展洪水风险识别、风险估计及制作洪水风险 地图和行动策略方案, 并将洪水风险地图和行 动策略方案等信息通过风险沟通平台反馈给 各个利益相关者, 如果该方案经多元协商能够 接受, 则进入风险方案执行阶段, 并将风险的
跟踪控制信息反馈给利益相关者; 如果该方案 经多元协商未能采纳, 则重新进行信息交流并 制定新的方案直至被接受。具体的流程详见图 3 所示的流域水库群防洪利益相关者的风险沟 通模式示意图。

\section{2. 基于智联网技术的流域水库群防洪利益 相关者风险沟通模式}

智联网的最初思想是黄崇福教授在研究 如何进行风险分析在线服务时产生的 ${ }^{[6-8]}$ 。通 俗地讲, 由互联网联结具有观察、演绎、推理 和解决问题能力的多个人 (智能体), 并通过 嵌入的模型集个体小智慧为群体大智慧的网 络, 称为智联网。严格定义为设 $A$ 是一个智能 体集合, $N$ 是 $A$ 使用的一个网络, $M$ 是处理 $A$ 所提供信息的模型, 三元体 $<A, N, M>$ 称为一 个智联网。图 4 是一个最简单的智联网示意图。 
Risk Analysis and Crisis Response in Big Data Era (RAC-16)

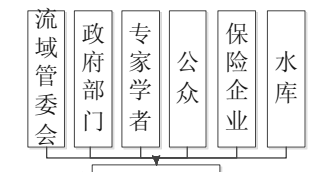

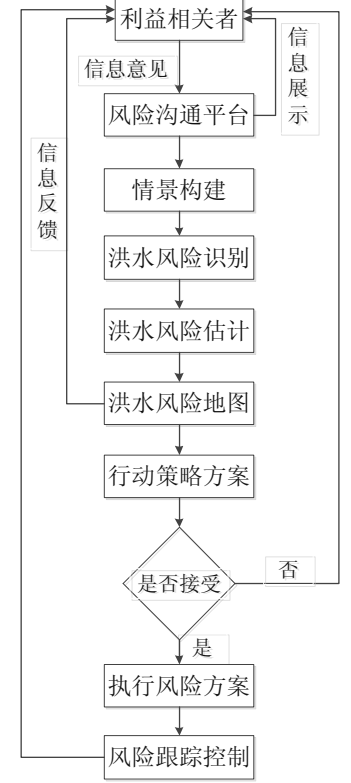

图 3. 流域水库群防洪利益相关者的风险沟通模式

基于智联网技术的流域水库群防洪利益 相关者风险沟通模式 (图 5) 研究主要是利用 博峦论、协同理论和复杂性科学理论, 针对保 险企业和公众居民追求的是关切区域损失量 最小的局部空间区域最优, 水库企业追求的是 自身蓄水量最大的效益最优, 地方政府追求的 是区域内部成本-效益的整体满意等不同偏好, 提出 “地理人-经济人-管理人”多元协商模式; 设计 “保险企业-公众-水库企业-地方政府-流 域协调委员会”防洪利益相关方多元协商机制; 基于洪涝灾害风险沟通 “准备-认知-谈判” 三 阶段特征, 研究防洪利益相关方洪涝灾害风险 沟通信息收集-发布-反馈流程, 在大体共识的 基础上进行协商, 快速确定风险管理策略, 为 水库群的防汛联合调蓄提供预警和决策提供 参考。

以台风来临之际的流域水库群防洪利益 相关者风险沟通为例, 以下简要介绍基于智联 网技术的流域水库群防洪利益相关者风险沟 通流程。首先明确我们的风险问题是解决流域

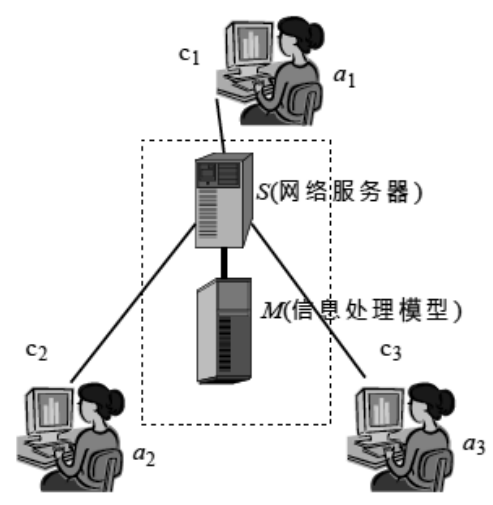

图 4. 智联网示意图

在水库群的联合调度决策问题, 决策的目标 是在保险企业和公众居民追求的是关切区域 损失量最小的局部空间区域最优, 水库企业追 求的是自身蓄水量最大的效益最优, 而地方政 府追求的是区域内部成本-效益的整体满意等 不同偏好的基础上取得尽可能大的共识; 然后 政府部门、流域管委会、专家学者、公众和普 通企业、保险企业及水库是等防洪利益相关 者结合智联网风险沟通平台所展示的流域实 时水情/雨情、卫星云图、气象雷达、天气预 报、水库实时水位/库容等信息, 在智联网风 险沟通平台上提供自身所涉及的位置信息、隐 患信息和调度建议等数据信息及意见关切; 接 下来专家学者可以利用风险沟通平台等收集 到的数据信息及意见关切构建流域洪水风险 情景; 进而开展洪水风险识别、风险估计及制 作洪水风险地图和行动策略方案, 并将洪水风 险地图和行动策略方案等信息通过风险沟通 平台反馈给各个利益相关者, 如果该方案经多 元协商能够接受, 则进入风险方案执行阶段, 
Risk Analysis and Crisis Response in Big Data Era (RAC-16)

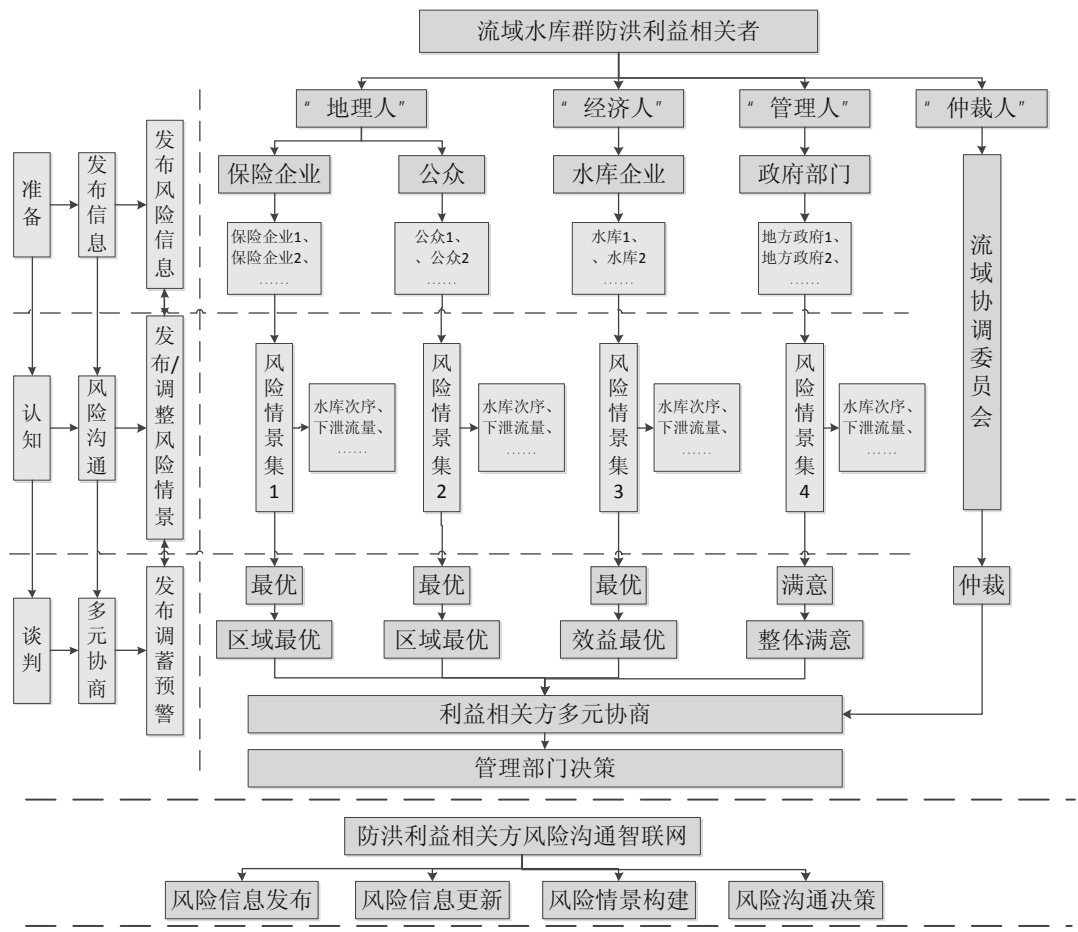

图 5. 基于智联网技术的流域水库群防洪利益相关者风险沟通框架

并将风险的跟踪控制信息反馈给利益相关者; 如果该方案经多元协商未能采纳, 则重新进行 信息交流并制定新的方案直至被接受。最后执 行多元协商后的流域水库群防洪行动方案。

\section{4. 结论和讨论}

同样的风险事件, 不同的利益相关者基于 不同的利益关切会有不同的风险认知。风险沟 通是利益相关者取得共识的重要风险治理工 具之一。在洪水灾害风险治理中, 水库的科学 泄洪调度是一项重要的研究课题, 而流域水库 群间的联合调度涉及到多方利益相关者的切 身利益。在防洪利益相关者之间就流域水库群 的防洪临灾联合调度开展有效的风险沟通是 在洪水无法避免的情况下采取联合措施来促 使流域洪水灾害的损失降到最低的重要途径。 在水库企业、政府部门、保险企业和公众居民 充分对区域洪涝灾害风险有效沟通的基础上, 综合考虑水库企业、政府部门、保险企业和公 众居民等各利益相关方的核心关切, 进行风险 辨识和估计, 并做出较为理想的临灾调度决策,
一方面可以在保证水库安全的前提下, 使水库 尽可能地多蓄水, 达到充分利用洪水资源, 保 障供水的目的, 另一方面也将丰富洪涝灾害风 险管理基本理论体系, 为政府水利部门进行流 域水库群的管理提供抓手, 增强流域防洪管理 的可操作性。这对于解决防洪与兴利矛盾以及 常规调度造成的洪水资源浪费问题具有重要 的理论和实践意义。

智联网技术可为风险沟通平台的搭建提 供有力的技术支撑, 但依然有许多技术不够成 熟, 还需要进一步完善并挖掘其应用潜能。

\section{参考文献}

[1] V.T. Covello, R.G. Peters, J.G. Wojtecki, et al. Risk communication, the west nile virus epidemic, and bioterrorism: responding to the communication challenges posed by the intentional or unintentional release of a pathogen in an urban setting. Journal of Urban Health-bulletin of the New York Academy of Medicine, 2001, 78(2): 382-3 
Risk Analysis and Crisis Response in Big Data Era (RAC-16)

91.

[2] 谢晓非,郑芯. 风险沟通与公众理性. 心理 科学进展, 2003, 11(4): 375-381.

[3] 祝雪花,姜丽萍, 董超群, 等. 台风等重大灾 害性事件的风险认知及预警机制. 灾害学, 2012, 27(2): 62-66.

[4] 钟景薡,叶琳. 基于公众对区域水灾感知的 灾害风险沟通探讨. 防灾科技学院学报, 2009, 11(4): 16-20.

[5] 李明,刘良明. 基于公众旱灾风险认知的灾 害风险沟通研究. 防灾科技学院学报, 2011, 13(3): 97-103.

[6] C.F. Huang. Internet of intelligences in risk analysis for online services. Journal of Risk Analysis and Crisis Response, 2011, 1(2): 110-117.

[7] W.D. Wang, S. Qiao, F.L. Zeng, J. Guo, C.F. Huang. An approach to ranking Integrated models for risk assessment by using the internet of intelligences. Journal of Risk Analysis and Crisis Response, 2016, 6(1): 2-9.

[8] C.F. Huang, Multiple Internet of intelligences for risk analysis, Journal of Risk Analysis and Crisis Response, 2014, 4(2): 61-71. 